\title{
Antihyperglycemic and Antioxidant Activity of Nanoemulsion Extracts of $M$. affine D. Don Leaves in Alloxan-Induced Rat
}

\author{
Safrida $^{1 *}$, Khairi ${ }^{1}$, Fani Fardinita ${ }^{1}$ \\ 1) Department of Biology Education, Faculty of Teacher Training and Education, Syiah Kuala University, Jl. Hasan Krueng Kalee \\ Darussalam Banda Aceh 23111, Indonesia
}

Submitted: 07 July 2020; Accepted: 28 October 2020; Published: 15 December 2020

\begin{abstract}
This study determined the antihyperglycemic and antioxidant activity of nanoemulsion extracts of $M$. affine leaves in alloxan-induced rats. This research used 24 male Wistar rats around three months old which grouped as normal (untreated), negative control (treated with carboxymethyl cellulose sodium/Na-CMC,), positive control (treated with glibenclamide), and various concentration (30,60, and 90\%) of nanoemulsion extract of $M$ affine leaves groups. The extract of $M$. affine leaves had an antioxidant activity with $\mathrm{IC}_{50} 5.30 \mathrm{ppm}$, categorized as a very strong antioxidant. Furthermore, the administration of this extract decreased glucose levels in antihyperglycemic rats. We concluded that $M$. affine leaves extract potential as antioxidants and be developed as an ingredient for diabetic drugs.
\end{abstract}

Keywords: diabetes, glucose levels, glibenclamide, M. affine, Rattus norvegicus strain wistar

Diabetes mellitus is a metabolic disorder that causes various complications. According to $\mathrm{WHO}$, diabetic's incidences in Indonesia in 2000 were around 8.4 million and will be increased to 21.3 million in 2030 (Suharmiati, 2003). Currently, diabetes treatment is done by consuming synthetic drugs and maintaining a diet. Clinical management using synthetic drugs may cause irritation, resistance, and infection. Glibenclamide is an antihyperglycemic drug that is commonly used for the treatment of type 2 diabetes mellitus and has promising new medical indications. However, this drug is associated with high rates of serious hypoglycemic episodes as a result of its pharmacological activity (Hernández-Abad et al., 2019). Glibenclamide spurs potassium channel activation (Assis et al., 2018).

One of the natural approaches to overcome hyperglycemia is by consuming natural ingredients available in the environment. One of the plants which has antihyperglycemic potential namely

\footnotetext{
*Corresponding author

Tel.: +62 82272517622

Email: saf_rida@unsyiah.ac.id

(C) 2020, J. Tropical Biodiversity Biotechnology (CC BY-SA 4.0)
}

"senggani" leaf from Aceh, Indonesia. Traditionally, Aceh people consume these leaves to reduce diabetes. Melastoma malabatbricum leaf contains triterpene, alpha-amyrin, quercitrin, quercetin, and kaempferol-3-O- (2 ", 6 " - di-Op-trans-coumaroyl) $\beta$ glucoside (Hasnah et al., 2010). Flavonoids play a role in preventing diabetes and its complications (Jack, 2012). Some research has proven that plants containing flavonoids are able to fight diabetes mellitus (Brahmachari, 2011). The administration of ethanolic extract of Melastoma malabathricum leaf by $400 \mathrm{mg} / \mathrm{kg}$ body weight can reduce glucose levels in diabetic mice (Sahara et al., 2019), ethanolic extract of $M$. malabathricum leaves has significant antidiabetic and antihyperlipidemic activity in diabetic rats (Karappasamy et al., 2014). However, this research uses $M$. affine, which belongs to the same genus as $M$. malabathrium, leaves extraction method carried out by nanoemulsion technique, one of the advantages of nanoemulsion technique is that it is easily absorbed by the small intestine wall thereby increasing the bioavailability of a compound. The rate of absorption of nano herbal in the human body can almost reach 100\% (Poulain \& Nakache, 1998). At present, there has never been reported the effect of 
nanoemulsion-based of $M$. affine leaves extract in diabetic conditions. The aim of this study was to determine the antihyperglycemic and antioxidant activity of nanoemulsion extracts of $M$. affine leaves in alloxan-induced rats.

The research was carried out at the Laboratory of Animal, Universitas Syiah Kuala. The preparation of $M$. affine leaves nanoemulsion extract was carried out at the Laboratory of Biology and Chemistry Faculty of Teacher Training and Education, Universitas Syiah Kuala, and Laboratory of Pharmacology, Faculty of Veterinary Medicine, Universitas Syiah Kuala. Antioxidant activity test was carried out at the Laboratory of Chemistry, Faculty of Teacher Training Education, Universitas Syiah Kuala.

This research used 24 male Wistar rats three months old with an average of body weight 180-200 gram. The rats were divided into 6 groups: $\mathrm{N}$ (normal group, untreated), NC (negative control, treated with carboxymethyl cellulose sodium/ $\mathrm{Na}-$ $\mathrm{CMC}$ ), PC (positive control, treated with glibenclamide), and nanoemulsion extract of $M$ affine leaves groups: P1 (30\% of nanoemulsion extract of M. affine leaves), P2 (60\% of nanoemulsion extract of M. affine leaves), and P3 (90\% of nanoemulsion extract of $M$. affine leaves). The extract treatment was given orally once a day for 21 days.

Three kilograms of $M$. affine leaves were weighed, washed thoroughly, and air-dried for \pm 3 days. After dry, these leaves were blended until smooth. Maceration was done with leaves powder and a $96 \%$ ethanol ratio of $1: 10$ for 2 days to withdraw all the compounds contained in M. affine leaves. The preparation nanoemulsion of $M$. affine leaves extract includes the oil phase and water phase. The oil phase is a mixture of $180 \mathrm{~mL}$ of M. affine leaves extract and the water phase consists of 180 gram of maltodextrin, $18 \mathrm{~mL}$ tween 80 , and $102 \mathrm{~mL}$ of phosphate buffer solution. Homogenization of the oil phase in the water phase was done using centrifugation at 15,000 rpm for 15 min (Safrida et al., 2020)

The Antioxidant activity test was done using the DPPH (2,2 -difenil -1-pikrilhidrazil) method. The test was carried with $0.5 \mathrm{~mL}$ sample solution at various concentrations $(2,4,6,8$, and $10 \mathrm{ppm})$ to create a standard curve. $3.5 \mathrm{~mL}$ of DPPH was added to each solution. Homogenization was processed with vortex and incubated at $37^{\circ} \mathrm{C}$ in a dark room. The absorbance was measured at the wavelength of $517 \mathrm{~nm}$ using a spectrophotometer (X Series UV VIS 100 DA-X) (Musri et al., 2017).

The use of experimental animals in this study is in accordance with the code of ethics with ethical clearance (Ref: 5/KEPH/I/2020) from the Faculty of Veterinary Medicine, Universitas Syiah Kuala. Rats were kept in animal cages. Cages were cleaned before used by spraying formalin $10 \%$ as a disinfectant. Cages were placed at room temperature and get indirect light. Animal cages were wire cages. Food and drink were administrated to rat in containers, cages were cleaned every day. The rats were acclimatized for 1 week and food was provided ad libitum. The initial blood glucose level was measured after being fasted for 8-12 h. Furthermore, rats were injected by intraperitoneal with alloxan 120 mg kg-1 body weight. Blood glucose was measured after alloxan induction. One week after alloxan injection, fasting blood glucose was measured to verify the incidence of hyperglycemic. Rats are declared hyperglycemic if glucose concentration above $200 \mathrm{mg} \mathrm{dL}^{-1}$, the rats were treated with the extract of $M$. affine orally.

Rat's blood glucose examination was done using Gluco Dr strips. Blood was drawn from the tip of the rat's tail with a little massage and then pierced with a sterile needle \pm as deep as $\leq 0.5 \mathrm{~cm}$. Blood was taken from the tail of the rats and then dropped on a blood glucose strip. The blood glucose level was indicated on the numbers read on the blood sugar strips. Examination of blood sugar levels was done on day $0,7,14$, and 21 after alloxan injection.

A compound has a very strong antioxidant if the IC50 is less than $50 \mathrm{ppm}$, strong (50-100 ppm), moderate (100-150 ppm), and weak (151-200 ppm). The smaller the IC50 value the higher the antioxidant activity (Musri et al., 2017). The results showed that nanoemulsion extract of $M$. affine leaves has strong antioxidant activity with $\mathrm{IC}_{50} 5.30 \mathrm{ppm}$ while the $\mathrm{IC}_{50}$ value of Vitamin $\mathrm{C}$ was $6.35 \mathrm{ppm}$ (Table 1). This means that the antioxidant activity of $M$. affine extract is categorized as a very strong antioxidant. It was reported that methanolic extract of Melastoma malabathricum leaves has high antioxidants properties (Suhaimy et al., 2017). Methanolic extract of Melastoma malabathricum leaves was considered as a compound which has a high antioxidant value (Mamat et al., 2013). M. affine is related to $M$. malabathrium, which belongs to the family Melastomataceae and genus Melastoma. Ethanolic extract of green grass jelly leaves was reported to have high antioxidant activity with $\mathrm{IC}_{50}$ 6.3 ppm (Mahadi et al., 2018).

Nanoemulsion extract of $M$. affine leaves have very strong antioxidant activity. This extract has the potential to reduce glucose concentration in diabetic rats. The results showed that glucose levels decreased after the administration of nanoemulsion extract of $M$. affine leaves. The average blood glucose level of each treatment including $\mathrm{N}$ (normal group, untreated), NC (negative control, given 
Table 1. Antioxidant Activity of Nanoemulsion Extract of $M$. affine Leaves.

\begin{tabular}{|c|c|c|c|c|c|c|c|c|}
\hline \multirow{2}{*}{ No. } & \multirow{2}{*}{$\begin{array}{c}\text { Control } \\
\text { (EtOH, } \\
\text { Absorba } \\
\text { nce) }\end{array}$} & \multirow{2}{*}{$\begin{array}{c}\text { Concentration } \\
\text { (ppm) }\end{array}$} & \multicolumn{2}{|c|}{ Absorbance } & \multicolumn{2}{|c|}{$\%$ Inhibition } & \multicolumn{2}{|r|}{$\mathrm{IC}_{50}$} \\
\hline & & & Vitamin C & $\begin{array}{c}\text { M. affine } \\
\text { leaves }\end{array}$ & Vitamin C & $\begin{array}{c}\text { M. affine } \\
\text { leaves }\end{array}$ & Vitamin C & M.affine leaves \\
\hline 1 & & 2 & 0.071 & 0.078 & 42.74 & 37.10 & & \\
\hline 2 & & 4 & 0.064 & 0.074 & 48.39 & 40.32 & & \\
\hline 3 & 0.124 & 6 & 0.063 & 0.051 & 49.19 & 58.87 & $6.35 \mathrm{ppm}$ & $5.30 \mathrm{ppm}$ \\
\hline 4 & & 8 & 0.058 & 0.047 & 53.23 & 62.10 & & \\
\hline 5 & & 10 & 0.057 & 0.043 & 54.03 & 65.32 & & \\
\hline
\end{tabular}

carboxymethyl cellulose sodium/Na-CMC), PC (positive control, given glibenclamide), P1 (given 30 $\%$ nanoemulsion extracts of $M$. affine leaf), P2 (60\% nanoemulsion extracts of $M$. affine leaf), and P3 (90 $\%$ nanoemulsion extracts of $M$. affine leaf) can be seen in Table 2.

The results showed that the initial blood glucose level of rats was in the range of $75-98 \mathrm{mg} /$ dL. According to Wolfensohn and LIoyd (2013), the range of normal blood glucose levels in rats is 50 $135 \mathrm{mg} / \mathrm{dL}$. The results showed that the administration of alloxan caused increases in blood glucose in rats (Table 2). This is in line with a previous study by Safrida and Sabri (2019) that alloxan can induce diabetes in rats.

At the first week of observations, the amount of blood sugar in PC (positive control, treated with glibenclamide), and treated nanoemulsion extract of $M$ affine leaves groups; P1 (30\% of nanoemulsion extract of $M$. affine leaves) and P2 (60\% of nanoemulsion extract of $M$. affine leaves) were decreased compared to diabetic rats, but had not reached normal blood sugar levels. The rat blood sugar levels in the P3 (90\% nanoemulsion extracts of $M$. affine leaves) treatment was almost close to normal rat blood sugar levels.

The administration nanoemulsion extract of M. affine leaves for 21 days was able to reduce the blood glucose level of rats to normal. This is presumably because $M$. affine leaves contain several bioactive compounds that have potency as antidiabetic. Mohd et al., (2012) reported that $M$. malabathricum extract contains bioactive compounds namely ursolic acid, 2-hydroxyursolic acid, asiatic acid, glycerol-1,2-dilinolenyl-3-O- $\beta$-D galactopyranoside, glycerol 1,2-dilinolenyl-3-O- (4,6di-O-isopropylidene) - $\beta$-D-galactopyranoside, methyl-2,5,6-trihydroxynaphtalene carbonate, flavonol glycoside derivatives, 2,5,6trihydroxynaphtoic carbonic acid, kaempferol-3-O( 2 ', 6'-di-Op-trans-coumaroyl) - $\beta$-glucoside, and quercitrin.

Quercetin is a type of flavonoid, a subclass of flavonols. It has a hypoglycemic ability to inhibit the enzyme alpha-amylase in the hydrolysis of carbohydrates. Quercetin is able to inhibit glucose

Table 2. Average of Blood Glucose Concentration of Rats in Various Treatments.

\begin{tabular}{|c|c|c|c|c|c|}
\hline \multirow{2}{*}{ Treatment } & \multirow{2}{*}{$\begin{array}{l}\text { Initial blood } \\
\text { glucose (mg/ } \\
\text { dL) }\end{array}$} & \multirow{2}{*}{$\begin{array}{l}\text { Blood glucose } \\
\text { after alloxan } \\
\text { injection }(\mathrm{mg} / \\
\mathrm{dL})\end{array}$} & \multicolumn{3}{|c|}{ Blood glucose levels (mg/dL) } \\
\hline & & & Day 7 & Day 14 & Day 21 \\
\hline $\mathrm{N}$ & $75,00 \pm 5,887 a$ & $75,00 \pm 5,887 a$ & $96,25 \pm 20,56^{a}$ & $86,50 \pm 1,91^{a}$ & $76,00 \pm 10^{a}$ \\
\hline PC & $85,25 \pm 5,315^{a}$ & $263,25 \pm 39,508^{b}$ & $173,75 \pm 14,31^{b}$ & $82,50 \pm 3,87^{a}$ & $87,75 \pm 4,11^{a}$ \\
\hline $\mathrm{NC}$ & $88,25 \pm 7,135^{a}$ & $239,75 \pm 41,732^{\mathrm{b}}$ & $216,25 \pm 46,77 \mathrm{c}$ & $247,50 \pm 77,73^{b}$ & $194,5 \pm 5,32^{\mathrm{b}}$ \\
\hline P1 & $74,00 \pm 2,708^{a}$ & $316,50 \pm 35,519^{b}$ & $157,00 \pm 17,26^{\mathrm{b}}$ & $104,75 \pm 6,50^{\mathrm{ab}}$ & $87,00 \pm 4,24^{a}$ \\
\hline P2 & $98,25 \pm 8,995^{a}$ & $307,00 \pm 73,787 \mathrm{~b}$ & $158,50 \pm 11,95^{b}$ & $98,25 \pm 8,57 a$ & $88,50 \pm 8,18 a$ \\
\hline P3 & $98,25 \pm 6,130^{a}$ & $259,50 \pm 61,733^{b}$ & $137,50 \pm 39,49 \mathrm{ab}$ & $91,25 \pm 8,53^{\mathrm{a}}$ & $82,5 \pm 10,34^{a}$ \\
\hline
\end{tabular}


transport by intestinal GLUT2 and GLUT5 which have a function in the absorption of glucose in the small intestine, so that quercetin is able to reduce blood glucose. Some evidence showed that flavonoids from vegetables and medicinal plants have a beneficial effect on diabetes by increasing glycemic control, lipid profile, and antioxidant status. Mechanisms of antihyperglycemic effects include reduction of carbohydrate absorption from the small intestine, inhibition of tissue gluconeogenesis, elevation absorption of tissue glucose, stimulation of insulin secretion from beta cells, and protection of the islets of Langerhans against degeneration (Ghorbani, 2017). Antioxidants can repair cells by capturing free radicals thus protecting the islets of Langerhans against damage (Musri et al., 2017)

The amount of rat blood glucose reached normal blood glucose levels after 14 and 21 days of treatment in all concentrations of nanoemulsion extract of $M$. affine leaves. Previous research by Karmilah (2018) showed that the ethanolic extract of M. affine leaves with the dose of $360 \mathrm{mg} / \mathrm{g}$ body weight could reduce the amount of blood sugar to normal with a duration of 28 days. According to Justina (2014), nanoemulsion is a technology that can change drug particles into a nano size. One of the advantages of nanoemulsion is that it is easily absorbed by the intestinal wall.

Nanoemulsion extract of $M$. affine leaves have high antioxidant activity and potentially reduce glucose levels in diabetic rats. Nanoemulsion extract of $M$. affine leaves has potency as a source of antioxidants and antihyperglycemic agents.

\section{ACKNOWLEDGMENTS}

We thank Dr. Hasanuddin, M.Si for his assistance in identifying $M$. affine.

\section{REFERENCES}

Assis KS, Araújo IGA, de Azevedo FLAA, Maciel PMP, Machado Calzerra NT, da Silva TAF, Assis VL, de Vasconcelos AP, Santos CAG, Meireles BRLA, Cordeiro AMTM, Araújo DAM, , Medeiros IA, 2018, Potassium Channel Activation Is Involved in the Cardiovascular Effects Induced by Freeze Dried Syaygiumjambolanum (Lam.) DC Fruit Juice. Biomed Res 1:1-12.

Brahmachari, G., 2011, Bio- Flavonoids with Promising Antidiabetic Potentials: A Critical Survey, Research Signpost, 187-212.

Ghorbani A., 2017, Mechanisms of Antidiabetic Effects of Flavonoid Rutin. Biomed Pharmacother. 96:305-312.
Hasnah M S, Deny S, Farediah A, Hiromitsu T, Mriko K, 2010, Amides, Triterpene and Flavonoids from the Leaves of Melastoma Malabathricum L. J Nat Med. 64(4):492-5.

Hernández-Abad VJ, Sánchez-González EG, Espinosa-Contreras C, Marroquín-Segura R, Mora-Guevara JLA, Flores-Cabrera Y, 2019, Controlled release of glibenclamide from monolithic silica subdermal implants produced by the sol-gel process and its use for hyperglycaemia treatment in a murine model. Mater SciEng C Mater Biol Appl. 1; 94:10091019.

Jack, 2012, Syntetis Of Antidiabetic Flavonoids and Their Derivative. Medical Research.

Justina, N., 2014, Produksi Nanoemulsi Ekstrak Temulawak dengan Metode Homogenisasi [Production of Temulawak Extract Nanoemulsion by Homogenization Method], Thesis, Bogor: Institut Pertanian Bogor.

Karappasamy B, Antony N, Veerabahu RM, 2014, Antidiabetic and Antihyperlipidaemic Activity of Ethanol Extract of Melastoma Malabathricum Linn. Leaf in Alloxan Induced Diabetic Rats. Asian Pac J Trop Biomed. 4(1): S442-S448.

Karmilah, 2018, Efek Antidiabetik Ekstrak Daun Senggani (Melastoma polyanthum BI.) pada Mencit (Mus musculus) Jantan yang Diinduksi Streptozotocin [Effects of Antidiabetic Extracts of Senggani (Melastoma polyanthum BI.) On Male Mice (Mus musculus) Induced Streptozotocin]. Jurnal Mandala Pharmacon Indonesia, 4(1), 28-32.

Mahadi, R, Mustafid Rasyiid, Krisnanda Surya Dharma, Lindia Anggraini, Rahma Nurdiyanti, Tri Rini Nuringtyas, 2018 , Immunomodulatory and Antioxidant Activity of Green Grass Jelly Leaf Extract (Cyclea barbata Miers.) In Vitro. J. Trop. Biodiv. Biotech., 3 (2), 73-79

Mamat, Siti Syariah, Mohamad Fauzi Fahmi Kamarolzaman, Farhana Yahya, Nur Diyana Mahmood, Muhammad Syahmi Shahril, Krystal Feredoline Jakius, Norhafizah Mohtarrudin, Siew Mooi Ching, Deny Susanti, Muhammad Taher, and Zainul Amiruddin Zakaria., 2013, Methanol extract of Melastoma malabathricum leaves exerted antioxidant and liver protective activity in rats. BMC Complement Altern Med. 13: 326. 
Mohd, Joffry S, Yob NJ, Rofiee MS, Meor Mohd Affandi MMR, Othman F, Abdah MA, Mohd Desa MN, Suhaili Z, Zakaria ZA., 2012, Melastoma malabathricum (L.) Smith: A review of its ethnomedicinal, chemical and pharmacological uses. Evid Based Complement Alternat. 13:258434.

Musri Musman, Safrida Safrida, Viqqi Kurnianda, Erlidawati Erlidawati., 2017, Evaluation of Antihyperglycemia Property from Syzygiumoleana (Magnoliopsida: Myrtaceae) Pericarp, Research Journal of Medicinal Plants, 11 (3), 100-106, 1819-3455.

Poulain N and Nakache E., 1998, Nanoparticles from vesicles polymerization. II. Evaluation of their encapsulation capacity $J$ Polym Sci A: Polym Chem. 36: 3035-3043.

Safrida S, and Sabri M., 2019, Effect of Muntingia calabura L. Stem Bark Extracts on Uric Acid Concentration and Renal Histopathology in Diabetic Rats. Medicina Journal, 55(10), 2-8.

Safrida S, K Khairil, W Artika and, R Rinaldi., 2020, Pandanus amaryllifolius Roxb. leaf extract prepared by nanoemulsion technique as a natural mouthwash. Journal of Physics: Conference Series. 1460 (1-7).

Sahara M, Maxwel Simanjntak, Yoridha Aulia, Yustina Zai, Masdalena., 2019, Uji Aktivitas Anti Diabetes Ekstrak Etanol Daun Senggani (Melastoma Malabathrium L) pada Mencit Jantan yang Diinduksi Aloksan [Anti-Diabetic Activity Test of Ethanol Leaf Melastoma Malabathrium L in Aloxan-induced Male Mice]. Seminar Nasional Teknologi KomputereSains (SAINTEKS) 1: 174 - 176.
Suhaimy NWI, Ahmad Khusairi Noor Azmi, Norhafizah Mohtarrudin, Maizatul Hasyima Omar, Siti Farah Md. Tohid, Manraj Singh Cheema, Lay KekTeh, Mohd. Zaki Salleh, Zainul Amiruddin Zakaria., 2017, Semipurified Ethyl Acetate Partition of Methanolic Extract of Melastoma malabathricum Leaves Exerts Gastroprotective Activity Partly via Its AntioxidantAntisecretory-Anti-Inflammatory Action and Synergistic Action of Several Flavonoid-Based Compounds.Oxid Med Cell Longev. 1: 6542631

Suharmiati., 2003, Pengujian Bioaktivitas Anti Diabetes Melitus Tumbuhan Obat [Testing the Anti-Diabetes Mellitus Bioactivity of Medicines]. Surabaya: Badan Riset Pengembangan dan Kesehatan. Pusat Riset dan Pengembangan Pelayanan dan Teknologi Kesehatan. Departemen Kesehatan RI.

Wolfensohn, S., dan Lloyd, M., 2013, Handbook of Laboratory Animal Management And Welfare,4thed., Wiley Blackwell,WestSussex. 